\title{
Using findings from the performance appraisal literature to inform the evalua- tion of students in higher education
}

\author{
Sara L. Mann \\ University of Guelph
}

\begin{abstract}
Decades of research in the management literature have guided managers on how to effectively motivate their employees, increase the performance of their employees, and evaluate the performance of their employees. Many of these findings could be applied to higher education, both in research and in practice. More specifically, the findings on performance management and evaluation in the management literature could be integrated into the literature on higher education. This integration could prove beneficial for academics, institutions, and students alike. This article provides recommendations for educators and opportunities for future research.
\end{abstract}

\section{RÉSUMÉ}

Des décennies de recherche dans la documentation relative à la gestion ont démontré comment réussir à motiver des employés, à accroître leur performance et à évaluer celle-ci. Bon nombre de ces conclusions pourraient être appliquées à l'enseignement supérieur, tant en recherche, qu'en pratique. Plus précisément, ce que l'on a découvert sur la gestion du rendement et l'évaluation, parmi la documentation portant sur la gestion, pourrait être intégré dans la littérature relative à l'enseignement supérieur. L'intégration de ces deux courants pourrait se révéler bénéfique pour les théoriciens, les institutions et les étudiants. Cet article fournit des recommandations pour les éducateurs et des opportunités pour de futures recherches. 
In the management literature, researchers have spent decades examining ways to motivate employees and increase their performance through effective performance evaluation. Despite the plethora of research in the education literature examining ways to motivate students and increase their academic performance (for example Ames, 1992; Ames \& Archer, 1988; Bandura, 1977, 1986; Greene \& Miller, 1996; Schunk, 1989), these two streams of literature have not been integrated. The findings from the management literature could be used to build on existing findings in the literature on higher education and suggest ways for educators to increase the motivation and performance of their students through effective performance evaluation. The intent of this article is threefold: to provide recommendations for educators that may be applicable from the performance appraisal literature; to provide ideas for future research and integration between the two disciplines, namely management and higher education; third, to raise awareness among higher education researchers that many cross-discipline opportunities exist.

\section{MOTIVATION}

Prior to presenting the findings from the performance appraisal literature, the findings on motivation within the management literature must be reviewed in context. The management literature states that motivation is a function of needs, values, cognition/goals, affect, and behaviour (Latham \& Pinder, 2005). This is likely equally true of student motivation. Seminal motivation theories include needs theories (for example, Mazlow's Hierarchy of Needs), which, as the name implies, suggest that individuals are motivated by different needs. Likewise, employee values - specifically, cultural, work, and personal values - have been shown to predict higher levels of motivation. See Latham and Pinder (2005) for a recent review of the motivation literature and evidence of the success of these theories in a workplace setting.

While research has found that employees are motivated by needs and values, process theories of motivation are perhaps more relevant to student motivation. Expectancy theory is a management theory that can transfer smoothly to the educational setting. Vroom's Expectancy Theory (1964) states that individuals are motivated by three beliefs. First, individuals must feel that their level of effort will lead to a corresponding level of performance. In other words, do employees feel that if they put in a great deal of effort, they will achieve a high level of performance? Self-efficacy, or a person's belief in their own ability to achieve their desired goal (Gist \& Mitchell, 1992), is the most critical component of this model: individuals without a high level of self-efficacy will not be motivated. In the educational context, do students feel that if they study hard, they will be able to perform well on the exam? Educators should be aware of this question, and first recognize students' levels of self-efficacy and then help improve those levels, perhaps by providing students with the appropriate tools and resources they need to complete the task. The second component of expectancy theory links motiva- 
tion to outcome. For example, does the student feel that performing well on an exam will actually lead to a high grade? While intuitively obvious, high performance does not always lead to high grades due to bias on the part of the instructor or grader. Therefore, the most critical learning here is to ensure performance is measured fairly and accurately, minimizing bias, a recommendation that will be discussed in further detail later in this paper. Expectancy theory also suggests that it is important that the individual values the reward. Whether or not the student actually values getting a high grade may be out of the educator's control, however, this insight may help in diagnosing a particularly low level of motivation.

Equity theory (Adams, 1963) can also be applied to students. Equity Theory describes a social comparison process whereby individuals compare their inputs and outputs to the inputs and outputs of others. Students, for example, will be aware of the ratio of their inputs (academic ability, amount of time spent studying, attending class) to their outputs (e.g. grades, amount of learning) and compare this to the input/ output ratio of their classmates. If they feel as though the relationship is inequitable (classmates are receiving higher grades for the same amount of effort or performance), they will reduce their inputs or effort. Again, educators must ensure that students feel that they are being treated in a fair and equitable manner. This often involves removing the bias involved in assessing performance, to be discussed in more detail later in this paper.

The concept of justice becomes particularly important here. Specifically, procedural justice is critical to the perception of fair treatment. Procedural justice (Folger \& Greenberg, 1985) determines the degree to which the process of evaluation is considered fair. In education, for example, is the evaluation process transparent (was a grading key provided to the students)? Was sufficient feedback given to the students? Was the exam or test valid and based on the content of the course? Was everyone given equal opportunity and access to materials for the course? Ensuring that individuals perceive that the entire process is fair is critical to increasing their motivation.

Interactional justice (Bies \& Moag, 1986) refers to perceived fairness based on the individual being treated with respect: merely treating people with respect can greatly impact their level of motivation. Ensuring justice, both procedural and interactional, is essential to increasing the motivation level of employees, and likely students as well. A recent article has applied some of the findings from the performance appraisal literature to the classroom, but only examined what students perceive as a fair assessment (Pepper \& Pathak, 2008). It should also be noted that despite high levels of procedural and interactional justice, some students may still feel they deserve more marks than are awarded.

Lastly, Locke and Latham's (1990) goal setting theory can also apply to education. Goal setting theory states that if individuals set goals, they will be more motivated to perform. However, in order for goal setting to be successful, the goals must be specific, relevant, and challenging. In addition, individuals must be committed to the goals, must participate in the setting of the goals, and, most importantly, must be provided feedback on the progress of the goals. 


\section{PERFORMANCE MANAGEMENT}

In the management literature, performance has been categorized into three dimensions - task, citizenship, and counterproductive). Academic performance (grades on an exam for example) could be considered a proxy for task performance. However, both citizenship performance and counterproductive performance should both be examined within the educational context as they may be critical to the overall success of the student. For example, citizenship performance is defined as "individual behaviour that is discretionary, not directly or explicitly recognized by the formal reward system, and that in the aggregate promotes the effective functioning of the organization" (Organ, 1988, p.4). In the context of postsecondary education, citizenship performance could be important in that some students may be more or less willing to help other students depending on a variety of factors. Findings that individual levels of citizenship behaviour lead to higher levels of team success (Podsakoff, MacKenzie, Paine, \& Bachrach, 2000) might also apply in an education setting. The predictors of citizenship behaviour (satisfaction, perceptions of fairness, commitment, and conscientiousness) (Podsakoff et al., 2000) would then become of interest. Researchers should examine whether citizenship behaviour can be increased in an education setting, whether the predictors from the management literature apply to education, and what the effects of citizenship behaviour in the classroom are. For example, perhaps citizenship behaviour increases the likelihood and outcome of collaborative and cooperative learning (e.g. Johnson, Johnson, \& Smith, 1998).

In the management literature, counterproductive behaviours are behaviors that violate the legitimate interests of the organization (Sackett \& Devore, 2001). In teams where at least one group member demonstrates a high level of counterproductive behaviour, group performance decreases over time (Budworth \& Mann, 2006). Education research should counterproductive behaviours' effects in the classroom, and whether the predictors from the management literature also apply in a classroom setting. Recognizing the multiple dimensions of student performance (in addition to grades) may be of value to educators and students.

\section{THE LITERATURE}

What we know about measuring employee performance should also be applied to measuring student performance. It is critical that the method of evaluation is valid, reliable, practical, and free from bias (Thorndike, 1949). With respect to validity, it is critical that the assessment tool is measuring the actual content of the course. Often students are frustrated that test or exam questions are not representative of the material covered in the course. Second, assessment tools should be reliable - consistently administered to all students (same time and place, with everyone given same access to prior information) and consistently graded. Third, the assessment tool should be practical. Of course, time constraints need to be taken into consideration, so there must be a balance between an optimal assessment 
tool and one practical from the educators' perspective. Lastly, the assessment tool should be free from bias. This is potentially the most difficult and yet most critical requirement. How can we minimize bias as much as possible and yet still keep the assessment tool practical? This may involve providing a grading key that is detailed, choosing an unbiased rater, and removing identity from the assignments (e.g. using student number only to identify the student).

The performance management literature shows that rater bias accounts for most of the variability in performance ratings (Scullen, Mount, \& Goff, 2000). Therefore, it is critical to train the grader so as to minimize the bias. In the world of work, individual performance often falls after a performance appraisal (Kluger \& DeNisi, 1996), most often because of a lack of appropriate feedback. Individuals perceive a low level of procedural justice if they feel feedback on their performance was either not provided at all, not timely, or not provided in a respectful manner. Educators should recognize the importance of providing feedback and realize the impact this can have on subsequent performance. Ideally, performance evaluation should not be a discrete event, rather continuous feedback should be provided throughout the term, and there should not be any surprises.

Another concept from the management literature that could be applied is 360 degree feedback, or feedback from multiple sources (Bracken, Timmreck, \& Church, 2001). In education, this could mean, for example, that students receive feedback from their peers as well as from their educator. Input from multiple sources takes into account the "multidimensional nature of jobs as seen by different constituencies" (London \& Smither, 1995, p. 804), and the fact that different populations (e.g., peers) have different opportunities to observe different aspects of an individual's performance (Murphy \& Cleveland, 1995). The caveat though, is that the peer evaluations need to be anonymous in order to be effective (Dominick, Reilly, \& McGourty, 1997). While there is a plethora of research in the education literature regarding peer evaluations, researchers should compare the findings in the management literature as well. For a recent review of the performance management literature, see Latham, Almost, Mann and Moore (2005) and Latham and Mann (2006).

\section{RECOMMENDATIONS}

It is important that research inform and influence teaching and vice versa. Applying the management theories to the education of students is an attempt at this integration. Based on the relevant literature presented in this article, the following are recommendations for educators based on findings in the management literature, specifically with respect to performance evaluation:

- Student performance should be measured accurately. Minimize bias when measuring performance, and train the grader appropriately. Keep in mind - that which gets measured and rewarded gets done. Therefore, ensure students understand what you are measuring, how you are measuring it, and that the reward (grade) is tied to a high level of performance. Also, ensure 
that feedback is timely, and that the assessment tool is valid, reliable, practical, and free from bias. Feedback from multiple sources should be collected where possible, but remember to keep peer evaluations anonymous.

- Recognize the importance of fairness. Procedural fairness (that students understand how their performance is measured and that it is free from bias) is particularly important. Interactional fairness (treating students with respect) will also go far in increasing their performance.

- Recognize that individuals are constantly engaging in a social comparison process, and therefore you need to treat students fairly, relative to each other.

- Have your students set goals that are specific, relevant, and challenging. In addition, students should be committed to the goals, should participate in the setting of the goals, and, most importantly, must be provided feedback on the progress of the goals.

\section{FUTURE RESEARCH}

Performance management and evaluation findings from the management literature should be examined to determine whether they are transferable and applicable to an educational context. Other concepts within the management literature might also be germane to higher education. For example, while there is extensive research on training in the education literature, researchers should also examine some key concepts from the training literature within the management discipline, such as Tharenou's (2001) concept of motivation to learn, or factors that influence the transfer of training (Baldwin \& Ford, 1988). Similarly, management literature findings on socialization and orientation may also apply in a classroom setting.

There is also a plethora of research surrounding team development (e.g. Tuckman \& Jensen, 1977), composition (e.g. Morgensen, Reider \& Campion, 2005), and performance (e.g. Arrow, McGrath, \& Berdahl, 2000; Kozlowski \& Bell, 2008). Many management studies use undergraduate students as subjects, and the relevant findings might be applicable to an educational setting.

Research on leadership styles and predictors of effective leadership might also to relevant to the classroom. Are behaviours that lead to effective leadership in the workplace also transferable to the classroom? Could professors adapt their leadership style accordingly?

\section{CONCLUSION}

The literature on higher education, specifically on the motivation and performance of students, is complex, thoughtful, and comprehensive. The purpose of this paper is not to suggest these issues are not being examined in the literature on higher education, but rather to suggest that researchers examine the findings in the management literature as well to see if any of those findings could be applied to students, specifically relating to performance evaluation. Given that we are researching such similar topics and issues, the purpose of this article is simply to raise awareness of our findings on motivation, performance, and evaluation, albeit 
with employees rather than students. In conclusion, this article suggests that there are opportunities to apply some of the findings from the management literature to higher education, in both research and practice. The possible integration of these two disciplines could prove fruitful for multiple stakeholders.

\section{REFERENCES}

Adams, J. S. (1963). Toward an understanding of inequity. Journal of Abnormal and Social Psychology, 67(5), 422-436.

Ames, C. (1992). Classrooms: Goals, structures, and student motivation. Journal of Educational Psychology, 84(3), 261-271.

Ames, C., \& Archer, J. (1988). Achievement goals in the classroom: Students' learning strategies and motivation processes. Journal of Educational Psychology, 80(3), 260-270.

Arrow, H., McGrath, J. E., \& Berdahl, J. L. (2000). Small groups as complex systems: Formation, coordination, development, and adaptation. Thousand Oaks, CA: Sage.

Baldwin, T., \& Ford, J. K. (1988). Transfer of training: A review and directions for future

Research. Personnel Psychology, 41(1), 63-105.

Bandura, A. (1977). Self-efficacy: Toward a unifying theory of behavioral change. Psychological Review, 84(2), 191-215.

Bandura, A. (1986). Social foundations of thought and action: A social cognitive theory. Englewood Cliffs, NJ: Prentice-Hall.

Bies, R. J., \& Moag, J. S. (1986). Interactional justice: Communication criteria for fairness. In B. Sheppard (Ed.), Research on Negotiation in Organizations (Vol. 1, pp. 43-55). Greenwich, CT: JAI Press.

Bracken, D. W., Timmreck, C. W., \& Church, A. H. (2001). The handbook of multisource feedback. San Francisco, CA: Jossey-Bass.

Budworth, M., \& Mann, S. L. (2006). A rotten apple spoils the bunch: The effect of individual counterproductive behaviors on team performance over time. Paper presented at the annual meeting of the Society for Industrial/Organizational Psychologists.

Dominick, P. G., Reilly, R. R., \& McGourty, J. W. (1997). The effects of peer feedback on team member behaviour. Group and Organization Management, 22(4), 508-520.

Folger, R., \& Greenberg, J. (1985). Procedural justice: An interpretive analysis of personnel systems. In K. M. Rowland \& G. R. Ferris (Eds), Research in Personnel and Human Resources Management (Vol. 3, pp. 141-183). Greenwich, CT: JAI Press.

Gist, M.E. \& Mitchell, T.R. (1992). Self-efficacy: a theoretical analysis of its determinants and malleability. Academy of Management Review, 17(2), 183-211. 
Greene, B. A., \& Miller, R. B. (1996). Influences on achievement: Goals, perceived ability, and cognitive engagement. Contemporary Educational Psychology, 21(2), 181-192.

Johnson, D., Johnson, R., \& Smith, K. (1998). Active learning: Cooperation in the college classroom (2nd ed.). Edina, MN: Interaction Book.

Kluger, A. N., \& DeNisi, A. (1996). The effects of feedback interventions on performance: A historical review, a meta-analysis, and a preliminary feedback intervention theory. Psychological Bulletin, 119(2), 254-284.

Kozlowski, S. W., \& Bell, B. S. (2008). Team learning, development and adaptation. In V. I. Sessa \& M. London (Eds.), Group Learning (pp.15-44). Mahwah, NJ: LEA.

Latham, G. P., Almost, J., Mann, S. L., \& Moore, C. (2005). New developments in performance management. Organizational Dynamics, 34(1), 77-87.

Latham, G. P. \& Mann, S. L. (2006). Advances in the science of performance appraisal: Implications for practice. International Review of Industrial and Organizational Psychology, 21, 295-338.

Latham, G. P. \& Pinder, C. C. (2005). Work motivation theory and research at the dawn of the twenty-first century. Annual Review of Psychology, 56(1), 485-516.

Locke, E. A. \& Latham, G. P. (1990). A theory of goal setting and task performance. Englewood Cliffs, NJ: Prentice Hall.

London, M., \& Smither, J.W. (1995). Can multi-source feedback change perceptions of goal accomplishment, self-evaluations, and performance-related outcomes? Theory-based applications and directions for research. Personnel Psychology, 48(4), 803-839.

Morgenson, F. P., Reider, M. H., \& Campion, M. A. (2005). Selecting individuals in a team setting: The importance of social skills, personality characteristics and teamwork knowledge. Personnel Psychology, 58(3), 583-611.

Murphy, K. R., \& Cleveland, J. N. (1995). Understanding performance appraisal: Social, organizational, and goal-based perspectives. Thousand Oaks, CA: Sage.

Organ, D. W. (1988). Organizational citizenship behavior: The "good soldier" syndrome. Lexington, MA: Lexington Books.

Pepper, M. B., \& Pathak, S. (2008). Classroom contribution: What do students perceive as fair assessment? Journal of Education for Business, 83(6), 360-368.

Podsakoff, P., MacKenzie, S., Paine, J., \& Bachrach, D. (2000). Organizational citizenship behaviors: A critical review of the theoretical and empirical literature and suggestions for future research. Journal of Management, 26(3), 513-563.

Sackett, P. R., \& Devore, C. J. (2001). Counterproductive behaviors at work. In N. Anderson, D. Ones, H. Sinangil \& C. Viswesvaran (Eds.), Handbook of Industrial, Work, and Organizational Psychology (Vol. 1, pp. 145-164). London, UK: Sage. 
Schunk, D. H. (1989). Self-efficacy and cognitive skill learning. In C. Ames \& R. Ames (Eds.), Research and motivation in education: Vol. 3. Goals and cognitions (pp. 13-44). San Diego, CA: Academic Press.

Scullen, S. E., Mount, M. K., \& Goff, M. (2000). Understanding the latent structure of job performance ratings. Journal of Applied Psychology, 85(6), 956-970.

Tharenou, P. (2001). The relationship of training motivation to participation in training and development. Journal of Occupational and Organizational Psychology, 74(5), 599-621.

Thorndike, R. L.. (1949). Personnel Selection. New York: Wiley, 1949.

Tuckman, B. W. \& Jensen, M. A. C. (1977). Stages of small group development revisited. Group and Organization Studies, 2(4), 419-442.

Vroom, V. H. (1964). Work and Motivation. New York: Wiley.

\section{CONTACT INFORMATION}

Sara L. Mann

Department of Business

University of Guelph

50 Stone Road East

Canada N1G 2W1

519-824-4120 (ext.56872)

smann@uogueph.ca

Sara Mann is an Associate Professor of Organizational Behaviour and Strategic Human Resource Management in the Department of Business at the University of Guelph. Sara completed an MBA at McMaster University, and a PhD in Management at the Rotman School of Management, University of Toronto. Sara's expertise includes performance appraisals and performance management, selection, and compensation. Sara's research is primarily within rural areas and the Agri-food sector, and is funded by both SSHRC and OMAFRA. 